\title{
Myocardial Infarction and Normal Coronary Arteries: The Experience of the Cardiology Department of Sfax, Tunisia
}

\author{
Leila Abid, Amine Bahloul, Zied Frikha, Souad Mallek, Dorra Abid, Malek Akrout, \\ Mourad Hentati and Samir Kammoun
}

\begin{abstract}
Objective The purpose of the present study is to describe our experience with patients who have a transmural myocardial infarction (MI) in the presence of a normal coronary artery. The clinical profile, demographic characteristics and outcomes of these patients are discussed.

Methods Between January 2006 and August 2011, 21 patients who presented with a Q-wave myocardial infarction were found to have normal coronary arteries. The prevalence rate of this entity was $1.5 \%$ (21 out of $1,400 \mathrm{Q}$ wave MI patients). These patients were characterized by their young age (the mean age $=44.95 \pm$ 14.86), male dominance (90.47\%), and a high prevalence of smoking $(85.71 \%)$. In this study, 4 patients have an evident spontaneous spasm shown on coronary angiography which disappeared after intracoronary injection of nitrates. Coagulation Disorders, such as activated protein C resistance (APC) resistance, protein C deficiency and antiphospholipid antibody syndrome were found in 4 of 12 patients who underwent systematic examination. One patient had a history of lung cancer which may be associated with a hypercoagulable state and may explain the occurrence of myocardial infarction with a normal coronary artery. The mean left ventricle ejection was $56.5 \pm 12$. The mean follow-up was $24 \pm 10$ months. Six patients developed residual chest pain which was generally easily controlled by anti-spastic therapy and no patient had a major cardiovascular event.

Conclusion Patients with Q-wave MI and with normal coronary arteries seem to have a good short and long-term prognosis especially when they are treated with an exclusive medical strategy.
\end{abstract}

Key words: coronary angiography, myocardial infarction, prognosis, aetiology

(Intern Med 51: 1959-1967, 2012)

(DOI: 10.2169/internalmedicine.51.6545)

\section{Introduction}

Q-wave myocardial infarction (MI) is generally due to the development of permanent arterial thrombosis of an atherosclerotic coronary artery. Mechanisms of thrombosis are complex. They include atherosclerotic plaque rupture, platelet activation, thrombus formation and coronary vasospasm. However, Q-wave MI may occur in subjects with normal coronary arteries. A number of hypotheses have been suggested to explain the factors related to the pathogenesis of this entity. These factors include coronary arterial vaso- spasm, thromboemblism with spontaneous or therapeutic lysis, hypercoagulable states and autoimmune vasculitis. The prevalence rate of MI with normal or near normal coronary arteries ranges from 1 to $12 \%$ depending on the studied population and the definition of a "normal" or "close to normal" coronary artery. The short and long term prognosis of these patients is generally favorable with a low risk of death and recurrence of myocardial infarction.

The purpose of the present study is to describe our experience with patients who have a transmural MI in the presence of normal coronary artery. The clinical profile, demographic characteristics and outcomes of these patients are 
discussed.

\section{Materials and Methods}

The following study is retrospective. It includes 21 patients with Q-wave MI and normal coronary arteries. They represent a sample among the 1,400 patients with Q-wave MI who were admitted to our institution between January 2006 and August 2011. The diagnosis of myocardial infarction was based on the occurrence of ischemic chest pain lasting >30 minutes and accompanied by ST segment (ST) segment elevation of at least $0.1 \mathrm{mV}$ in two contiguous electrocardiographic leads. They are followed by either an increase in the serum concentration of the creatine kinase myocardial band (MB) fraction of $>5 \%$ or the appearance of new $\mathrm{Q}$ waves which were not present during the initial electrocardiogram. Abnormal Q waves are those lasting 0.03 sec. at least $4 \mathrm{~mm}$ deep, and $>25 \%$ of the height of the ensuing $\mathrm{R}$ wave in all leads other than aVR or V1. With regard to these cases of Q-wave myocardial infarction, the Troponine concentration was not determined. Each patient received a curative anticoagulation and double antiaggregation with aspirin and clopidogrel. Nine patients received thrombolytic therapy with streptokinase using a standard dosage. Each patient underwent angiography of the coronary arteries in multiple projections within the same emergency unit or just after the acute episode. The investigation includes selective left coronary angiography (6 projections) as well as selective right coronary angiography (4 projections). Intracoronary isosorbide dinitrate is administered for each patient before angiography. A provocative test using intravenous methyergometrine was performed in only 3 patients with a normal coronary angiogram to identify coronary artery spasm. The test is considered positive when at least $70 \%$ focal reduction of luminal diameter is present. Our department has neither intravasucular ultrasound (IVUS) nor cardiac magnetic resonance imaging (MRI) which is significant for the understanding of the pathogenetic mechanism. Coronary angiograms were reviewed by two independent experienced angiographers. A normal coronary angiogram was defined by the absence of coronary lesions or the presence of a single lesion which does not exceed $30 \%$ of luminal diameter in one major pericardial vessel. The angiographic presence of thrombus is defined as a noncalcified filling defect outlined in at least three sides by contrast media. In case of the presence of thrombus, patients with thrombolysis in myocardial infarction (TIMI) flow 2 or 3 are included. The epidemiological, clinical, electrocardiographic, echocardiographic, and angiographic features of these 21 patients are reviewed.

Clinical conditions known to be associated with a hypercoagulable state, such as pregnancy, cancer, deficits in coagulation factors, oral contraceptive use were systematically sought. A follow-up was undertaken by consulting the patients' files and by telephone interview with each patient. The following data were analyzed: death (cardiac death or all cause mortality), recurrence of MI, need for revascularization, heart failure, ventricular arrhythmia, bleeding complication, stroke, thromboembolic event, left ventricular ejection fraction and medical treatment.

\section{Statistical analysis}

All continuous variables are expressed as the mean values \pm standard deviations. Categorical variables are expressed in the light of the numbers of patients or percentages.

\section{Results}

The current retrospective study highlights the experience of the cardiology department of Sfax in the management of patients with Q-wave MI and normal or relatively to normal angiogram. This entity of MI was found in 21 patients between January 2006 and August 2011 corresponding to $1.5 \%$ of the total patients hospitalized for Q-wave MI $(1,400$ patients) in the same period.

\section{The epidemiological characteristics}

The epidemiological characteristics of the studied patients are shown in Table 1.

Nine patients were less than 40 years old. Their mean age was 44.95+/-14.86 years (ranging from 25 to 71 years). Most of the patients were male (19 patients; 90.47\%). They were smokers (18 patients; $85.71 \%$ ) and had a significantly high pack-year history (22+/-16 pack-years). The prevalence of the other cardiovascular risk factors was low with a low rate of diabetes ( 2 patients; $9.52 \%$ ), hypertension (5 patients; $23.80 \%$ ), hypercholesterolemia (3 patients; $14.28 \%$ ) and family history of CAD (2 patients: $9.52 \%$ ). One patient (patient 3 ) had a history of lung cancer. Congenital coagulation disorders were investigated in only 12 patients. The results were positive in 4 patients; these anomalies were activated protein $\mathrm{C}$ resistance in one patient, the first patient, factor $\mathrm{V}$ leiden mutation in the second, antiphospholipid antibodies syndrome in the third and finally, protein $\mathrm{C}$ deficiency in the fourth. Five patients had a history of previous chest pain, and among 16 other patients, MI was inaugural.

\section{The electrocardiographic and echocardiographics features}

The electrocardiographic and echocardiographic features are summarized in Table 2. There was no predilection for a specific location of MI on the basis of ECG criteria. On transthoracic echocardiography, the left ventricle ejection fraction was depressed $(<55 \%)$ in only 5 of the examined patients $(23.80 \%)$. The mean left ventricle ejection was $56.5+/-12.11 \%$. The left ventricular motion revealed some form of abnormality in 16 patients (76.19). In general, there is a good correlation between the ECG location of MI and the echographic findings. Two patients had annular valve calcifications whereas 4 others had varying degrees of mitral regurgitation. 
Table 1. Epidemiological Characteristics

\begin{tabular}{|c|c|c|c|c|c|c|c|c|c|}
\hline Case No & $\begin{array}{l}\text { Age } \\
\text { (years) }\end{array}$ & Sex & HTA & Diabetes & Hypercho* & Heredity & $\begin{array}{l}\text { Cigarettes } \\
\text { smoking } \\
\text { (pack- } \\
\text { years) }\end{array}$ & $\begin{array}{l}\text { Hypercoagulate } \\
\text { state }\end{array}$ & $\begin{array}{l}\text { History of } \\
\text { previous chest } \\
\text { pain }\end{array}$ \\
\hline 1 & 45 & M & no & no & no & no & 40 & no & - \\
\hline 2 & 25 & M & no & no & no & no & 10 & APC resistance & - \\
\hline 3 & 65 & $\mathrm{~F}$ & yes & yes & yes & no & 0 & Lung cancer & $\begin{array}{l}\text { Yes/12 } \\
\text { months }\end{array}$ \\
\hline 4 & 56 & M & yes & no & yes & no & 40 & no & no \\
\hline 5 & 33 & M & yes & no & no & yes & 17 & no & no \\
\hline 6 & 31 & M & no & no & no & no & 16 & no & no \\
\hline 7 & 31 & M & no & no & no & no & 7 & no & no \\
\hline 8 & 21 & M & no & no & no & no & 0 & no & Yes/6 months \\
\hline 9 & 53 & M & no & no & no & no & 25 & no & no \\
\hline 10 & 49 & M & no & no & no & no & 30 & no & no \\
\hline 11 & 51 & M & no & no & no & no & 50 & no & Yes/6 months \\
\hline 12 & 32 & M & no & no & no & no & 10 & $\begin{array}{l}\text { Protein C } \\
\text { deficiency }\end{array}$ & no \\
\hline 13 & 51 & M & no & no & no & no & 52 & no & Yes/2 months \\
\hline 14 & 30 & M & no & no & no & no & 20 & no & No \\
\hline 15 & 71 & $\mathrm{~F}$ & no & yes & no & no & 0 & no & no \\
\hline 16 & 35 & M & no & no & no & no & 15 & no & no \\
\hline 17 & 48 & M & no & no & no & no & 25 & no & no \\
\hline 18 & 32 & M & no & no & no & no & 10 & no & no \\
\hline 19 & 67 & M & yes & no & no & no & 35 & no & no \\
\hline 20 & 57 & M & no & no & no & yes & 30 & no & no \\
\hline 21 & 61 & M & yes & no & yes & no & 40 & no & Yes/9 months \\
\hline
\end{tabular}

\section{The angiographic characteristics}

Each patient underwent a coronary angiography artery during the same hospitalization with an average of $3.42+/-$ 1. 98 days (range 0 to 7 days). An emergency coronary angiography was performed in 3 patients. The angiographic characteristics of the patients are summarized in Table 3 . The coronary angiography was strictly normal in 16 patients (76.19\%). It showed minimal lesions in the infarct related vessel in 5 patients. No complication occurred during angiography. Four patients developed during the coronary angiography a spontaneous vasospasm expressed by chest pain and ST-segment elevation on electrocardiogram. All the signs of ischemia disappear after the injection of isosorbide dinitrate in intraluminal coronary vessel. Three patients have a provocative test for spasm during catheterization. One patient has a positive response with proximal obstruction of the right coronary artery, chest pain and ST depression.

\section{Initial phase of myocardial infarction (Table 4)}

The clinical and therapeutic features of the initial phase of patients admitted to MI and normal coronary artery are summarized in Table 4. The clinical course was not benign in all instances. The average duration of pain was $81 \mathrm{~min}-$ utes. It showed a rapid reperfusion. Two patients developed a congestive heart failure and were treated with furosemide. One of these two patients presented cardiogenic shock which was stabilized after treatment by dobutamine.

Premature ventricular contractions developed in 3 patients. In addition, one of them had developed no sustained monomorphic ventricular tachycardia. All of the patients were treated with lidocaine. No patient developed conductive trouble. Three patients described residual angina that is self-limited and not associated with ECG changes. Each patient received curative anticoagulation during the acute phase. Nine of the patients $(42.85 \%)$ received lowmolecular-weight heparin. Similarly, each received double anti-aggregation with aspirin and clopidogrel. Two patients also received glycoprotein IIb /IIIa inhibitors.

Nine patients received thrombolytic therapy. In eight of these patients, thrombolysis seemed to be successful. Nevertheless, with the other patient, chest pain and ST elevation persisted. This remaining patient underwent an emergency coronary angiography. There was no case of in-hospital death. At discharge, each patient took aspirin. However, 16 patients (76\%) had aspirin in addition to either clopidogrel or ticlopidine and 17 patients have received beta-blockers while 5 patients received statins.

\section{Follow-up (Table 5)}

A mean follow-up of $24 \pm 10$ months (from 5 to 48 months) showed neither death nor the recurrence of Q-wave MI. Each patient has received aspirin. Either a residual angina or atypical chest pain was observed in 6 patients; 4 of them were treated with calcium antagonists and nitrates. Only three patients become completely asymptomatic. In the fourth patient who was treated with calcium antagonist, atypical chest pain has persisted. One patient had atypical chest pain after stopping treatment. The pain disappeared with the retreatment with beta blockers and nitrates. One pa- 
Table 2. Electrocardiographic and Echocardiographics Features

\begin{tabular}{|c|c|c|c|c|c|}
\hline Case No & $\begin{array}{l}\text { ECG site } \\
\text { of MI }\end{array}$ & LVEF $(\%)^{*}$ & $\begin{array}{l}\text { Myocardial } \\
\text { motion } \\
\text { abnormalities }\end{array}$ & $\begin{array}{l}\text { Mitral or aortic } \\
\text { valve anomaly }\end{array}$ & $\begin{array}{l}\text { Mitral } \\
\text { regurgitation }\end{array}$ \\
\hline 1 & inferior & 68 & no & no & no \\
\hline 2 & $\mathrm{AL}$ & 57 & $\begin{array}{l}\text { Anterior } \\
\text { hypokinesia }\end{array}$ & no & Yes grade 1 \\
\hline 3 & inferior & 62 & $\begin{array}{l}\text { Inferior } \\
\text { hypokinesia }\end{array}$ & no & no \\
\hline 4 & AS & 57 & no & no & no \\
\hline 5 & IL & 63 & $\begin{array}{l}\text { Inferior } \\
\text { hypokinesia }\end{array}$ & no & no \\
\hline 6 & $\mathrm{AL}$ & 60 & $\begin{array}{l}\text { Anterior } \\
\text { hypokinesia }\end{array}$ & $\begin{array}{l}\text { Mitral valve } \\
\text { calcification }\end{array}$ & no \\
\hline 7 & IL & 65 & $\begin{array}{l}\text { Inferior } \\
\text { hypokinesia }\end{array}$ & no & no \\
\hline 8 & $\begin{array}{l}\text { Apico- } \\
\text { lateral }\end{array}$ & 65 & no & no & no \\
\hline 9 & IL & 65 & $\begin{array}{l}\text { Inferior } \\
\text { hypokinesia }\end{array}$ & no & no \\
\hline 10 & AS & 58 & $\begin{array}{l}\text { Anterior } \\
\text { hypkinesia }\end{array}$ & no & no \\
\hline 11 & Inferior & 60 & no & no & no \\
\hline 12 & $\begin{array}{l}\text { Apico- } \\
\text { lateral }\end{array}$ & 58 & Apical akinesia & no & no \\
\hline 13 & $\mathrm{AL}$ & 45 & $\begin{array}{l}\text { Antero-lateral } \\
\text { hypokinesi }\end{array}$ & no & Yes/grade 1 \\
\hline 14 & Inferior & 65 & no & no & no \\
\hline 15 & $\mathrm{AL}$ & 30 & $\begin{array}{l}\text { Global } \\
\text { hypokinesia }\end{array}$ & $\begin{array}{l}\text { Aortic valve } \\
\text { calcification }\end{array}$ & Yes/ grade 2 \\
\hline 16 & IL & 62 & $\begin{array}{l}\text { Inferior } \\
\text { hypokinesia }\end{array}$ & no & no \\
\hline 17 & $\begin{array}{l}\text { Apico- } \\
\text { lateral }\end{array}$ & 63 & $\begin{array}{l}\text { Lateral } \\
\text { hypokinesia }\end{array}$ & no & no \\
\hline 18 & $\begin{array}{l}\text { Antero- } \\
\text { apical }\end{array}$ & 60 & $\begin{array}{l}\text { apical } \\
\text { hypokinesia }\end{array}$ & no & no \\
\hline 19 & AS & 57 & $\begin{array}{l}\text { Anterior } \\
\text { hypokinesia }\end{array}$ & no & no \\
\hline 20 & Inferior & 70 & $\begin{array}{l}\text { Inferior } \\
\text { hypokinesia }\end{array}$ & no & no \\
\hline 21 & $\mathrm{AL}$ & 45 & $\begin{array}{l}\text { anterior } \\
\text { hypokinesia }\end{array}$ & no & Yes/grade 2 \\
\hline
\end{tabular}

tient has presented with a non-elevated ST myocardial infarction with acute chest pain, ST depression in anterior leads, and elevation of troponins, just after 24 months. Coronary angiography has been performed 3 days after the previously mentioned complications become normal.

\section{Discussion}

\section{The prevalence and epidemiological features:}

Coronary atherosclerosis is considered the most common cause of MI (1). The coronary thrombosis has been superimposed on a fixed atherosclerotic plaque which is usually the triggering event in the pathogenesis of MI (2-4).

The occurrence of Q-wave MI in the presence of normal or close to normal coronary arteries has been documented in several reports.

The prevalence of MI and the normal coronary arteries ranges from $1 \%$ to $12 \%$ according to the mode of investigation and the population studied $(5,6)$. With the examined patients, the prevalence rate is $1.5 \%$. The reason for this relatively low prevalence is the restriction of the study to patients presenting a $\mathrm{Q}$-wave MI, to the various degrees of the definition of a "normal" or close to normal" angiogram and to the number of vessels involved. Most of the studies include both Q-wave and no Q-wave MI. They have defined a close to normal coronary artery as that with either a stenosis of less than $50 \%$ (7-9) or of $70 \%$.

The definition of a close to normal lesion has less been stricter than $30 \%$. They are limited to only one major artery. The present study is characterized by the young age of the patients, the predominance of men and the high rate of smoking. It may be contrasted with a low prevalence of the other cardiovascular risk factors. Risk factors as such may be compared with patients bearing the MI and coronary artery disease. In their study, Rosemblat and Selzer (10) show that patients with myocardial infarction and normal angiogram are presented with a few cardiovascular risk factors, apart from smoking, are compared with those having coronary lesions.

\section{Mechanism of MI}

Coronary spasm: Coronary spasm is considered as a classic factor of myocardial infarction with normal coronary arteries $(11,12)$. The high frequency of residual chest pain and the efficiency of antispastic medication on symptoms 
Table 3. Angiographic Characteristics

\begin{tabular}{|c|c|c|c|c|c|c|c|}
\hline Case No & $\begin{array}{l}\text { Time from } \\
\text { infarction(days) }\end{array}$ & LAD & LCX & RCA & $\begin{array}{l}\text { Spontaneous } \\
\text { spasm }\end{array}$ & Complication & $\begin{array}{l}\text { Provocative } \\
\text { test for } \\
\text { spasm }\end{array}$ \\
\hline 1 & urgent & 0 & 0 & 0 & no & 0 & \\
\hline 2 & urgent & Irreg $<30 \%$ & 0 & 0 & no & 0 & \\
\hline 3 & 3 & 0 & 0 & 0 & no & 0 & \\
\hline 4 & urgent & 0 & 0 & 0 & no & 0 & \\
\hline 5 & 4 & 0 & Irreg $<30 \%$ & 0 & yes & 0 & \\
\hline 6 & 5 & 0 & 0 & 0 & no & 0 & $\begin{array}{l}\text { Negative } \\
\text { response }\end{array}$ \\
\hline 7 & 4 & 0 & Irreg $<30 \%$ & 0 & no & 0 & \\
\hline 8 & 2 & 0 & 0 & 0 & yes & 0 & \\
\hline 9 & 7 & 0 & 0 & 0 & no & 0 & $\begin{array}{l}\text { Positive } \\
\text { response }\end{array}$ \\
\hline 10 & 3 & 0 & 0 & 0 & no & 0 & \\
\hline 11 & 3 & 0 & 0 & 0 & yes & 0 & \\
\hline 12 & 2 & 0 & 0 & 0 & no & 0 & \\
\hline 13 & 3 & 0 & 0 & 0 & no & 0 & \\
\hline 14 & 6 & 0 & 0 & 0 & no & 0 & \\
\hline 15 & 5 & 0 & 0 & 0 & no & 0 & \\
\hline 16 & 4 & 0 & 0 & 0 & no & 0 & \\
\hline 17 & 7 & 0 & 0 & 0 & no & 0 & $\begin{array}{l}\text { Negative } \\
\text { response }\end{array}$ \\
\hline 18 & 3 & 0 & 0 & 0 & no & 0 & \\
\hline 19 & 5 & Irreg $<30 \%$ & 0 & 0 & yes & 0 & \\
\hline 20 & 2 & 0 & Irreg $<30 \%$ & 0 & no & 0 & \\
\hline 21 & 4 & 0 & 0 & 0 & no & 0 & \\
\hline
\end{tabular}

suggest a role of vasospasm in the pathogenesis of MI. Coronary spasm may be a significant factor in the pathogenis of MI and normal coronary artery. However, it is not observed in all patients. Again, in their study, Raymond et al. found that coronary artery spasm is present in five of the 16 patients $(31 \%)$ in whom an ergonovine maleate test is performed (13). The same prevalence was found by Legrand et al. (14) and Lindsay and Pichard (15). They evaluated, respectively, 18 and nine patients. In the current study, four patients bear an evident spontaneous spasm. It is shown in coronary angiography. It disappears after the administration of nitrates. With the other patients, vasospasm has not been proven despite a residual chest pain in 5 of these patients. Hence, it is interesting to note that among these 5 patients, calcium antagonists have suppressed or reduced chest pain, while beta blockers are ineffective. Although the relationship between coronary spasm, angina, and electrical changes in the ECG is certain in studies (16-18), the role of coronary spasm as a cause of myocardial necrosis has been widely discussed (19). Many reports imply that vasospasm may be the triggering factor leading to thrombosis of $\mathrm{MI}$ and normal coronary artery $(5,20,21)$. In fact, an intense and prolonged coronary spasm with complete occlusion of the artery may lead to stasis and coronary thrombosis. Another hypothesis suggests that even a slight spasm, producing a turbulent blood flow, may cause endothelial damage and result in coronary thrombosis and transmural myocardial infarction.

The coronary arterial embolism: The embolism is one of the coronary arteries with lysis of a fresh occluding thrombus. It is subsequent to the thrombolytic therapy which is often associated with Q-wave MI and normal angiogram (22). In fact, the thrombus or embolus occluding luminal vessel at the early stage of MI may disappear before coronary angiogram. Each of which may explain the absence of possible thrombus (23).

Kereiakes et al. described 42 patients with over $50 \%$ residual coronary stenosis 90 minutes after thrombolytic therapy and show that the stenosis is reduced to less than $50 \%$ on repeated angiography 7 to 10 days later (24). Coronary embolism is generally associated with valvular heart disease, mural thrombus, prosthetic valve disease, and the left atrial myxoma. In this study, only two patients have respectively mitral and aortic valve calcification. Anomalies as such may serve as an intracoronary source of emboli with spontaneous recanalization.

The congenital coagulation abnormalities: The congenital coagulation abnormalities have also been hypothesized as a possible mechanism of myocardial infarction with normal coronary arteries (25). Owing to the small size of the population sample in previous studies, there is no conclusive answer (26-28). A multicentre study has found a higher prevalence rate of factor $\mathrm{V}$ Leiden in patients with myocardial infarction and normal coronary arteries. They may be compared with patients bearing myocardial infarction as well as coronary artery lesions or even healthy subjects (29). In this study, congenital disorders of coagulation including APC resistance, protein $\mathrm{C}$ deficiency, factor $\mathrm{V}$ leiden mutation and antiphospholipid antibodies syndrome were found in only two of the 12 patients in whom such abnormalities are systematically sought.

Cancer and MI with normal coronary artery: Cancers were traditionally associated with venous thrombosis. However, they may be associated with arterial thrombosis. Additionally, they may be evoked as a possible etiology of MI with coronary normal artery. The embolic complications appear to be one of the most common paraneoplastic syn- 
Table 4. Initial Phase of Myocardial Infarction

\begin{tabular}{|c|c|c|c|c|c|c|c|c|c|c|c|c|c|}
\hline Case No & $\begin{array}{l}\text { Circ. Of } \\
\text { infarct }\end{array}$ & $\begin{array}{l}\text { Duration } \\
\text { of pain }\end{array}$ & $\begin{array}{l}\text { Peak of } \\
\text { CPK }\end{array}$ & $\begin{array}{l}\text { Anti- } \\
\text { agregation }\end{array}$ & $\begin{array}{l}\text { Anti- } \\
\text { coag. }\end{array}$ & Throm & $\begin{array}{l}\text { Heart } \\
\text { failure }\end{array}$ & Shock & Arryth & $\begin{array}{l}\text { Cond. } \\
\text { Trouble }\end{array}$ & $\begin{array}{l}\text { Residual } \\
\text { angina }\end{array}$ & $\begin{array}{l}\text { Delay } \\
\text { from } \\
\text { infarct }\end{array}$ & $\begin{array}{l}\text { ECG } \\
\text { chang } \\
\text { es } \\
\end{array}$ \\
\hline 1 & Rest & $\begin{array}{l}240 \\
\text { minutes }\end{array}$ & 3,200 & Asp-clop. & UNFH & $\begin{array}{l}\text { yes/fail } \\
\text { ure }\end{array}$ & no & no & no & no & no & - & - \\
\hline 2 & Rest & 60 minutes & 840 & Asp-clop- & LMWH & no & no & no & no & no & no & - & - \\
\hline 3 & Rest & $\begin{array}{l}120 \\
\text { minutes }\end{array}$ & 1,236 & Asp-clop & LMWH & no & no & no & no & no & yes & 3 & no \\
\hline 4 & $\begin{array}{l}\text { Hyperten } \\
\text { sive peak }\end{array}$ & 30 minutes & 2,245 & Asp-clop & LMWH & no & no & no & no & no & no & - & - \\
\hline 5 & Rest & 90 minutes & 1,725 & Asp-clop-s & UNFH & $\begin{array}{l}\text { yes/suc } \\
\text { cess }\end{array}$ & no & no & $\begin{array}{l}\text { yes/ } \\
\text { VPB/ } \\
\text { NSVT }\end{array}$ & no & no & - & - \\
\hline 6 & Rest & 60 minutes & 658 & Asp-clop & LMWH & no & no & no & no & no & no & - & - \\
\hline 7 & Rest & 30 minutes & 728 & Asp-clop- & UNFH & $\begin{array}{l}\text { yes/suc } \\
\text { cess }\end{array}$ & no & no & no & no & no & - & - \\
\hline 8 & Rest & 60 minutes & 1,465 & Asp-clop & LMWH & no & no & no & no & no & no & - & - \\
\hline 9 & effort & 60 minutes & 1,224 & Asp-clop & UNFH & $\begin{array}{l}\text { yes/suc } \\
\text { cess }\end{array}$ & no & no & no & no & no & - & - \\
\hline 10 & Rest & 30 minutes & 680 & $\begin{array}{l}\text { Asp-clop- } \\
\text { Gp inh }\end{array}$ & UNFH & no & no & no & $\begin{array}{l}\text { Yes/ } \\
\text { VPB }\end{array}$ & no & no & - & - \\
\hline 11 & Rest & $\begin{array}{l}120 \\
\text { minutes }\end{array}$ & 875 & Asp-clop & UNFH & $\begin{array}{l}\text { yes / } \\
\text { success }\end{array}$ & no & no & no & no & yes & 1 & no \\
\hline 12 & Rest & $\begin{array}{l}180 \\
\text { minutes }\end{array}$ & 798 & $\begin{array}{l}\text { Asp-clop- } \\
\text { Gp inh }\end{array}$ & UNFH & no & yes & no & no & no & no & - & - \\
\hline 13 & Rest & $\begin{array}{l}120 \\
\text { minutes }\end{array}$ & 2,378 & Asp-clop & LMWH & no & yes & yes & no & no & no & - & - \\
\hline 14 & Rest & 60 minutes & 1,227 & Asp-clop & UNFH & $\begin{array}{l}\text { yes/suc } \\
\text { cess }\end{array}$ & no & no & no & no & no & - & - \\
\hline 15 & Rest & 30 minutes & 540 & Asp-clop & UNFH & no & no & no & no & no & no & - & - \\
\hline 16 & Rest & 60 minute & 1,482 & Asp-clop & NFWH & $\begin{array}{l}\text { no/ } \\
\text { success }\end{array}$ & no & no & no & no & no & 3 & no \\
\hline 17 & Rest & 90 minutes & 720 & Asp-clop & LMWH & no & no & no & $\begin{array}{l}\text { Yes/ } \\
\text { VPB }\end{array}$ & no & no & - & - \\
\hline 18 & Rest & 60 minutes & 898 & Asp-clop & LMWH & no & no & no & no & no & no & - & - \\
\hline 19 & Rest & 60 minutes & 1,580 & Asp-clop-s & UNFH & $\begin{array}{l}\text { yes/suc } \\
\text { cess }\end{array}$ & no & no & no & no & no & - & - \\
\hline 20 & Rest & $\begin{array}{l}120 \\
\text { minutes }\end{array}$ & 980 & Asp-clop-s & UNFH & $\begin{array}{l}\text { yes/suc } \\
\text { cess }\end{array}$ & no & no & no & no & no & - & - \\
\hline 21 & Rest & 30 minutes & 1,520 & Asp-clop & LMWH & no & no & no & no & no & no & - & - \\
\hline
\end{tabular}

dromes in patients with lung cancer $(30,31)$. These patients have a hypercoagulable state which is related to the production caused by cancer cells of the substances that interact with platelets, the coagulation system and fibrinolysis. These indicated factors have direct procoagulant actions on endothelial cells (32). Again, in our study, one patient (patient 3) had a history of lung cancer. This cancerous situation may be associated with a hypercaogulable state explaining the occurrence of myocardial infarction with normal coronary artery.

The role of smoking: Smoking is a major risk factor in the development of cardiovascular disease. Various mechanisms including platelets function disturbance and endothelial dysfunction have been entailed. Previous studies have suggested that platelets can be activated during chronic smoking (33-35). In fact, platelet activation plays an important role in the genesis of vascular obstructive syndromes. It does so because of its role in the initiation of thrombosis and because of the potential contribution of platelet-related growth factors to the atherogenic process.

Nowak et al. (36) demonstrated that smoking does vascular damage by causing abnormalities in the biosynthesis of both prostacyclin and thromboxane A2 among apparently healthy individuals who are chronic smokers. These results indicate that smoking induces both platelet dysfunctions with increased platelets aggregation and platelets adhesion with the development of micro vascular lesions. Another study found that ultra structural damage and platelets adhesion in low-shear zones have been described in the aortas of rats exposed to cigarette smoke (37). These micro-lesions created by smoking can serve an initiating factor for the development of MI on apparently normal arteries. Roule et al. (38) proposed an algorithm to summarize the different etiologies of MI with angiographically normal coronary arteries found in their cohort and in the literature.

The clinical, electrocardiographic and echocardiographic features: The clinical presentation and ECG features are the same with those found in patients with obstructive atherosclerotic artery disease. No predilection for the site of MI has been shown. Raymond et al. (13); Raizner and Chahine (39) have found similar results. These findings are in contrast with those of other studies that have reported a higher prevalence of anterior wall involvement $(40,41)$. On echocardiography, the present study showed a signifi- 


\section{Table 5. Long Term Prognosis}

\begin{tabular}{|c|c|c|c|c|c|c|c|}
\hline Case No & $\begin{array}{l}\text { Follow-up } \\
\text { duration }\end{array}$ & $\begin{array}{l}\text { Residual angina } \\
\text { or atypical chest } \\
\text { pain }\end{array}$ & $\begin{array}{l}\text { Delay } \\
\text { from } \\
\text { infarct }\end{array}$ & $\begin{array}{l}\text { Therapy } \\
\text { instituted }\end{array}$ & $\begin{array}{l}\text { Evolution } \\
\text { after } \\
\text { treatment }\end{array}$ & Stress test & $\begin{array}{l}\text { CV major } \\
\text { event }\end{array}$ \\
\hline 1 & 48 & no & - & - & asymptomatic & - & no \\
\hline 2 & 5 & no & - & - & asymptomatic & - & no \\
\hline 3 & 33 & $\begin{array}{l}\text { Atypical chest } \\
\text { pain }\end{array}$ & - & - & $\begin{array}{l}\text { Atypic chest } \\
\text { pain }\end{array}$ & - & no \\
\hline 4 & 42 & no & -- & - & asymptomatic & - & no \\
\hline 5 & 16 & Residual angina & 2 months & CA-nitrates & $\begin{array}{l}\text { Atypical } \\
\text { chest pain }\end{array}$ & Yes/negative & no \\
\hline 6 & 27 & no & - & - & asymptomatic & - & no \\
\hline 7 & 9 & no & - & - & asymptomatic & - & no \\
\hline 8 & 36 & no & - & - & asymptomatic & - & no \\
\hline 9 & 44 & Residual angina & 8 months & CA-nitrates & asymptomatic & - & no \\
\hline 10 & 12 & no & - & - & asymptomatic & - & no \\
\hline 11 & 18 & $\begin{array}{l}\text { Atypical chest } \\
\text { pain }\end{array}$ & 3 & CA-nitrates & asymptomatic & - & no \\
\hline 12 & 24 & no & - & - & asymptomatic & - & no \\
\hline 13 & 12 & $\begin{array}{l}\text { Atypic chest } \\
\text { pain(arrest of } \\
\text { traitment) }\end{array}$ & 3 months & BB-nitrates & Dyspnea & - & no \\
\hline 14 & 33 & NESTMI & 24 & AC-nitrates & asymptomatic & - & no \\
\hline 15 & 21 & No & 5 & $\begin{array}{l}\text { Diuretics- } \\
\text { AC- }\end{array}$ & Dyspnea & - & no \\
\hline 16 & 7 & no & - & - & - & - & no \\
\hline 17 & 44 & no & - & - & - & - & no \\
\hline 18 & 28 & no & - & - & - & - & no \\
\hline 19 & 34 & no & - & - & - & - & no \\
\hline 20 & 20 & Residual angina & 4 months & AC-nitrates & asymptomatic & - & no \\
\hline 21 & 24 & no & - & - & - & - & no \\
\hline
\end{tabular}

cantly higher left ejection fraction. This may be related to the younger age of the patients and increased contractility of the non infarct zone which has been demonstrated in patients with MI and with minimal coronary artery disease. The well-preserved global left ventricular function might also be associated with smaller infarct size compared to that in patients with obstructive coronary artery diseases. This may be due to rapid reperfusion in patients with normal coronary artery compared with patients with pathological coronary arteries.

Follow-up: The follow-up data are consistent with those of others in terms of the favorable prognosis of the examined patients $(2,8,20)$. Short term follow-up for these patients showed that complications such as arrhythmia, heart failure, and cardiogenic shock were generally less common, and that their prognosis was usually acceptable. In terms of morbidity, apart from the residual angina that occurred in 5 of the the present study patients and was easily controlled by calcium antagonists and nitrate derivates. No other major cardiovascular event such as recurrent MI, heart failure, and sudden cardiac death was observed. In their study, Da Costa et al. (42) found a $95.5 \%$ survival rate in the follow-up of patients with a normal coronary arteriogram at 3 years. Golzio et al. (43) reported a survival rate of $100 \%$ at 10 years in patients with zero-vessel disease. In agreement with these two previous studies $(32,33)$, the present study found a high survival rate of $100 \%$ at two years in 21 patients with myocardial infarction and normal coronary arteries.

\section{Limitations of the study}

Related to the small size and the retrospective nature of this study, some etiological factors of Q-wave MI with normal angiogram may be ignored. These causative factors were found only in one-third of patients. Thus, the search for coagulation factor deficiency was achieved in only 12 patients. On the other hand, these results may be explained by the limitations of the technique of angiography. In fact a normal coronary angiogram does not necessarily mean structurally normal coronary artery. It occurs as such because coronary angiography may misidentify atherosclerotic plaques with outward growth. The intravascular ultrasound (IVUS) was not systematically implemented as it should be due to the retrospective nature of the current study. It was carried out in just 6 patients in the literature and shows an absence of atherosclerosis in two cases $(44,45)$ in addition to inconspicuous signs of atherosclerosis in the other cases $(46,47)$. Thus, prospective studies on the pathophysiological mechanisms using new technologies such as intravascular ultrasound (48) would allow better analysis of the vessel structure.

\section{Conclusion}

The above-mentioned study is an investigation of the prevalence rate, epidemiological, clinical, and hemodynamic profile of 21 patients with Q-wave MI and normal coronary arteries. Although a number of reports have addressed the 
examined entity previously, this study comes up with several medical features that may be of useful for the forthcoming similar research. First, it determines the epidemiological profile of patients with Q-wave MI and normal coronary arteries relate to a young age group, with male dominance. Second, cigarette smoking is significantly higher and uniformly present in the studied patients. Third, an association is noted between the examined entity and the conditions of hypercoaguable state including paraneoplasic syndrome and inherited coagulation disorder. A mean follow-up of two years showed a favorable short and long-term prognosis in the patients under exclusive medical treatment.

The authors state that they have no Conflict of Interest (COI).

\section{References}

1. Libby P, Theroux P. Pathophysiology of coronary artery disease. Circulation 111: 3481-3488, 2005.

2. Kawai C. Pathogenesis of acute myocardial infarction: novel regulatory systems of bioactive substances in the vessel wall. Circulation 90: 1033-1043, 1994.

3. Arbustini E, Dai Bello B, Morbini P, et al. Plaque erosion is a major substrate for coronary thrombosis in acute myocardial infarction. Heart 82: 269-272, 1999.

4. Libby P. Current concepts of the pathogenesis of the acute coronary syndromes. Circulation 194: 365-372, 2001.

5. Sharifi M, Frohlich TG, Silverman IM. Myocardial infarction with angiographically normal coronary arteries. Chest 107: 36-40, 1995.

6. Alpert JS. Myocardial infarction with angiographically normal coronary arteries. Arch Int Med 154: 265-269, 1994.

7. Fragmin and Fast Revascularisation during In Stability in Coronary artery disease (FRISC II) Investigators. Invasive compared with non-invasive treatment in unstable coronary-artery disease: FRISC II prospective randomized multicenter study. Lancet 354: 708-715, 1999.

8. Ambrose JA, Dangas G. Unstable angina. Current concepts of pathogenesis and treatment. Arch Intern Med 160: 25-37, 2000.

9. Monassier JP, Jacquemin L, Roth O, et al. Non ST elevation acute coronary syndromes and normal coronary angiography: Is it truly good news? AnnCardiolAngeiol (Paris) 57275-57283, 2008 (in French).

10. Rosemblat A, Selzer A. The nature and clinical features of myocardial infarction with normal coronary arteriogram. Circulation 55: 578-580, 1977.

11. Heupler FA. Syndrome of symptomatic coronary arterial spasm with nearly normal coronary angiograms. Am J Cardiol 45: 873881, 1979.

12. Di Clemente D, Borghi A, Morgagni CL, Costa GM, Rusticalli G, Bugiardini R. Acute myocardial infarction with normal coronary arteries: role of microvascular dysfunction. Cardiologia 39: 827834, 1994.

13. Raymond R, Lynch J, Underwood D, Leatherman J, Razavi M. Myocardial infarction and normal coronary arteriography: ten year clinical and risk analysis of 74 patients. J Am Coll Cardiol 11: 471-477, 1988.

14. Legrand V, Deliege M, Henrard L, Boland J, Kulbertus H. Patients with myocardial infarction and normal coronaryarteriogram. Chest 6: 678-685, 1982.

15. Lindsay J, Pichard AD. Acute mycocardial infarction withnormal coronary arteries. Am J Cardiol 54: 902-904, 1984.

16. Kawano H, Ogawa H. Endothelial function and coronary spastic angina. Intern Med 44: 91-99, 2005.

17. Rigatelli G, Rossi P, Docali G. Normal angiogram in acute coronary syndromes: the underestimated role of alternative substrates of myocardial ischemia. Int J Cardiovasc Imaging 20: 471-475, 2004.

18. Germing A, Lindstaedt M, Ulrich S, et al. Normal angiogram in acute coronary syndrome-preangiographic risk stratification, angiographic findings and follow-up. Int J Med 99: 19-23, 2005.

19. Arnett EN, Roberts W. Acute myocardial infarction and angiographically normal coronary arteries: an unproven combination. Circulation 53: 395-400, 1976.

20. Benacerraf A, Scholl JM, Achard F, Tonnelier M, Lavergne G. Coronary spasm and thrombosis associated with myocardial infarction in patient with normal coronary arteries. Circulation 67: 1147-1150, 1983.

21. Halcox JP, Schenke WH, Zalos G, et al. Prognosis value of coronary vascular endothelial dysfunction. Circulation 106: 653-658, 2002.

22. Gonzalez M, Hernandez E, Aranda JM, Lindres E, Cortes F, Cintron G. Acute myocardial infarction due to intracoronary occlusion after elective cardioversion for atrial fibrillation in a patient with angiographic nearly normal coronary arteries. Am Heart J 102: 932-934, 1981.

23. Kardasz I, De Caterina R. Myocardial infarction with normal coronary arteries: a conundrum with multiple aetiologies and variable prognosis: an update. J Intern Med 261: 330-348, 2007.

24. Kereiakes DJ, Topol EJ, George BS, Stack RS, Abbottsmith CW, Ellis S. Myocardial infarction with minimal coronary atherosclerosis in the era of thrombolytic reperfusion. J Am Coll Cardiol 17: 304-312, 1991.

25. Brecker SJD, Stevenson RN, Roberts R, Uthayakumar S, Timmis $\mathrm{AD}$, Balcon R. Acute myocardial infarction in patients with normal coronary arteries. BMJ 307: 1255-1256, 1993.

26. Holm J, Zöller B, Svensson PJ, et al. Myocardial infarction associated with homozygous resistance to activated protein $\mathrm{C}$. Lancet 344: 952-953, 1994.

27. Dacosta A, Tardy-Poncet B, Isaaz K, et al. Prevalence of factor V leiden (APCR) and other inherited thrombophilias in young patients with myocardial infarction and normal coronary arteries. Heart 80: 338-340, 1998.

28. Lande G, Dantec V, Trossaert M, et al. Do inherited prothrombotic factors have a role in myocardial infarction with normal coronary arteriogram? J Intern Med 244: 543-544, 1998.

29. Mansourati J, Da Costa A, Munier S, et al. Prevalence of factor V Leiden in patients with myocardial infarction and normal coronary angiography. Thromb Haemost 83: 822-825, 2000.

30. Zuffa M, Kubancok J, Rusnák I, Mensatoris K, Horváth A. Early paraneoplastic syndrome in medical oncology: clinicopathological analysis of 1694 patients treated over 20 years. Neoplasma 31: 231-236, 1984.

31. Bréchot JM. Thrombosis and lung cancer. Rev Mal Respir 22: $8 \mathrm{~S}$ 33-8S37, 2005 (in French).

32. Donati MB. Cancer and thrombosis. Haemostasis 24: 128-131, 1994.

33. Ambrose JA, Barua RS. The pathophysiology of cigarette smoking and cardiovascular disease: an update. J Am Coll Cardiol 43: 1731-1737, 2004.

34. Mustard JF, Murphy EA. Effect of smoking on blood coagulation and platelet survival in man. Br Med J 1: 846, 1963.

35. Fuster V, Chesebro JH, Frye R, Elveback LR. Platelet survival and the development of coronary artery disease in the young adult: effects of cigarette smoking strong family history and medical therapy. Circulation 63: 546, 1981.

36. Nowak J, Murray JJ, Oates JA, FitzGerald GA. Biochemical evidence of a chronic abnormality in platelet and vascular function in healthy individuals who smoke cigarettes. Circulation 76: 6-14, 
1987.

37. Boutet M, Bazin M, Turcotte H, Lagace R. Effects of cigarette smoke on rat thoracic aorta. Artery 7: 56, 1980.

38. Roule V, Sabatier R, Lognoné $T$, et al. Thrombus in normal coronary arteries: Retrospective study and review of case reports. Arch Cardiovasc Dis 104: 216-226, 2011.

39. Raizner AE, Chahine RA. Myocardial infarction with normal coronary arteries. In: The Heart. Hurst JW, Ed. Update I, McGraw Hill, New York, 1979: 147-166.

40. Lindsay J, Bichard AD. Acute myocardial infarction with normal coronary arteries. Am J Cardiol 54: 902-904, 1984.

41. Legrand V, Deliege M, Henrad L, Boland J, Kulbertus H. Patients with myocardial infarction and normal coronary arteriogram. Chest 82: 678-685, 1982.

42. Da Costa A, Isaaz K, Faure E, Mourot S, Cerisier A, Lamaud M Clinical characteristics, aetiological factors and long-term prognosis of myocardial infarction with an absolutely normal coronary angiogram; a 3-year follow-up study of 91 patients. Eur Heart J 22: 1459-1465, 2001.
43. Golzio PG, Orzan F, Ferrero P, et al. Myocardial infarction with normal coronary arteries: ten-year follow-up. Ital Heart J 5: 732738, 2004.

44. Klein AJ, Casserly IP, Messenger JC. Acute left main coronary arterial thrombosis- a case series. J Invasive Cardiol 20: E243-E246, 2008.

45. Van Langenhove G, Vermeersch P, Serruys PW. Thrombus overlying the main stem crista: a three-dimensional reconstruction. Heart 85: 178, 2001.

46. Haude M, Altmann C, Eick B, et al. Analysis of vessel wall morphology, blood flow velocity, and the hemostatic system in a patient with a large intracoronary thrombus. CathetCardiovascDiagn 43: 298-305, 1998.

47. Kurisu S, Inoue I, Kawagoe T, et al. Acute myocardial infarction associated with myocardial bridging in a young adult. Intern Med 43: 1157-1161, 2004.

48. Rioufol G, Finet G, Ginon I, et al. Multiple atherosclerotic plaque rupture in acute coronary syndrome. A three-vessel intravascular ultrasound study. Circulation 106: 804-808, 2002.

(C) 2012 The Japanese Society of Internal Medicine http://www.naika.or.jp/imindex.html 